短報

\author{
発熱と白血球増多を伴わず，脳出血で発症した \\ Staphylococcus warneri による感染性心内膜炎の 1 例
}

\author{
種田 朝音1) 今野 卓哉1) 小野 純花 ${ }^{11}$ \\ 徳武 孝允 ${ }^{1)}$ 小野寺 理 ${ }^{1 *}$ *
}

\begin{abstract}
要旨：症例は僧帽弁閉鎖不全症を有する 50 歳男性. 右前頭葉の皮質下出血を発症した. CT 血管造影で微小脳 動脈瘤を認め, 発熱と白血球増多はなかったが, 爪の線状出血と Janeway 病変から感染性心内膜炎を疑い, 血液 培養から Staphylococcus warneri（S. warneri）を検出し診断した．抗菌薬と緊急開頭クリッピング術で良好な転 機を得た. S. warneri はコアグラーゼ陰性ブドウ球菌で, 皮膚に常在し, 自己弁に感染性心内膜炎を起こすことは 極めてまれである．本例は発熱や白血球増多を伴わず，皮質下出血で発症した点が特異であった．本菌は病原性 が低く炎症反応にそしいことがあり注意を要する.
\end{abstract}

（臨床神経 2021;00:000-000）

Key words : Staphylococcus warneri, コアグラーゼ陰性ブドウ球菌, 感染性心内膜炎, 感染性脳動脈瘤,

皮質下出血

はじめに

感染性心内膜炎は，診断が遅れると致死的な転帰をとりう る.今回我々は，炎症所見を伴わずに皮質下出血で発症した Staphylococcus warneri (S. warneri) による感染性心内膜炎の 症例を経験した。. S. warneri は病原性の低いコアグラーゼ陰 性ブドウ球菌であり，炎症所見を伴わず潜在性の経過の感染 性心内膜炎となりうるため, 脳出血で発症した場合に早期診 断が難しい，時機を逸さず適切に診断するために，本菌の特 徵を知ることが重要であると考え, 報告する.

\section{症例}

症例 : 50 歳, 男性

主訴：左上下肢が動かない, 吕律が回らない

既往歴：45 歳時に健診で心雑音を指摘され，48 歳時に僧

帽弁閉鎖不全症と診断され手術待機中であった。

家族歴：兄は 38 歳で胸部大動脈瘤破裂により死亡.

現病歴 : 2020 年 3 月下旬, 自宅の居間で座ってテレビを見 ていたところ，左上肢が動かないことに気がついた，立ち上 がろうとしたが左下肢が動かず立ち上がることができなかっ た。呂律も回らず，自ら救急要請した。発症から約 1 時間後 に当院に救急搬送された．頭部 CT で右前頭葉皮質下に高吸
収域を認め, 脳出血の診断で入院した。

入院時現症 : 身長 $170 \mathrm{~cm}$, 体重 $62.4 \mathrm{~kg}$, BMI 21.59 , 体温 $36.6^{\circ} \mathrm{C}$, 心拍数 $126 \mathrm{bpm}$, 血圧 $170 / 80 \mathrm{mmHg}, \mathrm{SpO}_{2} 97 \%$ （室 内気). 胸部に Levine V/VI 度の沉収縮期雑音を聴取した。左 第 3 指抢よび左第 4 趾の爪に線状出血を認めた (Fig. 1A, B). 右足底に淡い無痛性の斑状紅斑を認めた (Fig. 1C). 神経学 的には, 頭痛はなく意識は清明で, 顔面を含む重度の左片麻 痺と構音障害, 嚥下障害を認めた。

入院時検査所見：白血球数 $8,380 / \mu l$ と増加な $<, \mathrm{CRP}$ $2.69 \mathrm{mg} / \mathrm{d} l$ であった. $\mathrm{Hb} 11.7 \mathrm{~g} / \mathrm{d} l$ と貧血を認めた。肝機能, 腎機能には異常なく, 電解質は基準範囲内であった。糖尿病, 脂質異常症はなかった. BNP $28.2 \mathrm{pg} / \mathrm{ml}$ と軽度高值であっ た。凝固線溶系に異常はなかった。

画像所見：頭部単純 CT で, 右前頭葉皮質下に推定 $37.8 \mathrm{ml}$ の内部が不均一な血腫像を認めた（Fig. 1D）.

入院後経過：カルシウム拮抗薬で収縮期血圧 $150 \mathrm{mmHg}$ 以 下にコントロールした。発症第 2 日目に撮影したCT 血管造 影で, 血腫の近傍に微小脳動脈瘤を疑う結節性造影病変を認 めた (Fig. 1E). 発熱や白血球増多はなかったが, 手術適応 のある弁膜症と, 爪の線状出血, 足底の Janeway 病変から, 感染性心内膜炎による感染性脳動脈瘤破裂を疑った。同日, 血液培養を 3 セット提出しメロペネム $6.0 \mathrm{~g}$ /日を開始した. 発症第 3 日目に血液培養 3 七ット全てから S. warneri を検出

*Corresponding author: 新潟大学脳研究所脳神経内科〔 $\bar{\top} 951-8585$ 新潟市中央区旭町通 1 番町 757〕

1) 新潟大学脳研究所脳神経内科

(Received March 7, 2021; Accepted March 23, 2021; Published online in J-STAGE on July 17, 2021)

doi: 10.5692/clinicalneurol.cn-001613 

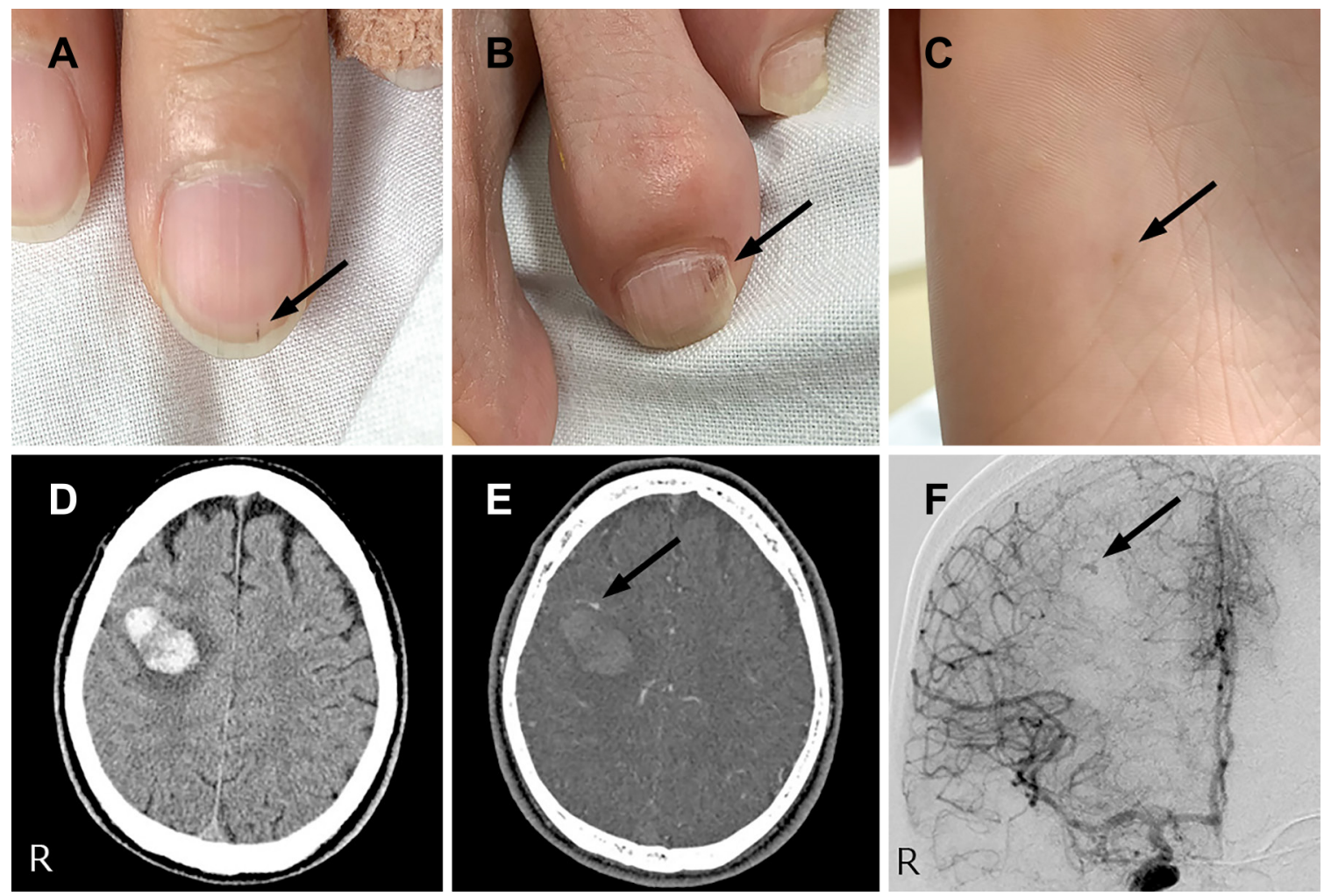

Fig. 1 Physical findings and brain images.

Splinter hemorrhages of the middle finger of the left hand and of the fourth finger of the left foot (A, B, arrows). Janeway lesion on the bottom of the foot (C, arrow). Brain CT shows subcortical hemorrhage in the right frontal lobe (D). CT angiography shows a microaneurysm near the hemorrhage (E, arrow). Digital subtraction angiography shows a microaneurysm located distal to the right prefrontal artery (F, arrow).

した．同日よりバンコマイシンを併用した，同日の血管撮影 で右前前頭動脈の遠位に約 $2 \mathrm{~mm}$ の微小脳動脈瘤を認め (Fig. 1F)，同日中に緊急開頭クリッピング術を㧍こなった。 動脈瘤の病理所見は, 動脈壁の破壊と内弾性板の欠失, 不整 に肥厚した膠原線維による血管壁の変性を認め, 感染性脳動 脈瘤として矛盾しなかった，術中に行った経食道心エコーで， 僧帽弁前尖の逸脱と弁瘤形成抢よび同部位からの逆流を認め た。発症第 5 日目に, 起因菌の薬剤感受性にもとづき抗菌薬 をぺニシリン G 2,400 万単位/日へ変更した。発症第 10 日目 に提出した血液培養は 3 セットとも陰性であった，発症第 26 日目の血管撮影で, 出血の責任部位であった脳動脈瘤は消失 し，新規の脳動脈瘤も生じていないことを確認した、ペニシ リン $\mathrm{G}$ は血液培養陰性化から約 6 週間継続した。構音障害, 嚥下障害ともに改善し, 左上肢に麻痺が残存したものの, 左 下肢の麻痺は著明に改善し歩行可能になった。発症第 45 日 目にリハビリテーション目的に転院した．

\section{考察}

本症例は，高血圧症の既往のない比較的若年者に生じた皮 質下出血の症例である。身体所見と頭部画像所見から感染性 心内膜炎による感染性脳動脈瘤破裂を疑い, 血液培養で $S$. warneri を検出した. 感染性心内膜炎としては発熱や白血球増 多といった感染徴候を欠いていたことが特徴的であった。

S. warneri はコアグラーゼ陰性ブドウ球菌の一種で, 健康 な成人の $50 \%$ に見られる皮膚の常在菌である ${ }^{1)} .2,781$ 例の 感染性心内膜炎症例を前方視的に解析した研究では, 起因菌 としてコアグラーゼ陽性ブドウ球菌であるStaphylococcus aureus (S. aureus) が $31 \%$ と最多で, Streptococcus viridans (S. viridans) が $17 \%$ と次いで多く，コアグラーゼ陰性ブドウ 球菌の頻度は $10 \%$ 程度である ${ }^{2)}$.コアグラーゼ除性ブドウ球 菌の病原性は低く，人工弁や心内デバイス関連感染性心内膜 炎の起因菌となるが, 自己弁症例で検出されることはまれで ある. 中でもS. warneri は極めてまれであり, 自己弁感染性 心内膜炎（native valve endocarditis，以下 NVE と略記）1,504 例の前方視的研究では，99 例（6.6\%）でコアグラーゼ陰性 ブドウ球菌を検出しているが, S. warneri は 1 例もなかった ${ }^{3)}$.

S. warneri による NVE 症例は渉猟した限りこれまでに 7 例 報告されている (Table 1)。一般に, 感染性心内膜炎では 9 割以上の症例で $38^{\circ} \mathrm{C}$ 以上の発熱を ${ }^{2}$, 約半数で白血球増多を 認めるが, 既報の S. warneri によるNVE 7 例のうち, 発症時 に発熱を伴った症例, $10,000 / \mathrm{mm}^{3}$ 以上の白血球增多を認めた 症例は, ともに 2 例 $(28.6 \%)$ のみであり ${ }^{4) \sim 6)}$, 感染徵候に そしい，本例も，発熱㧍よび白血球増多がなく既報例の特徴 
Table 1 Histories and laboratory findings of native valve endocarditis caused by Staphylococcus warneri.

\begin{tabular}{|c|c|c|c|c|c|c|}
\hline Age (y) & Sex & Medical histories & $\begin{array}{c}\text { Time from last surgery } \\
\text { to onset }\end{array}$ & $\begin{array}{l}\text { Fever } \\
\text { at onset }\end{array}$ & $\begin{array}{l}\text { Leukocyte count } \\
\qquad\left(/ \mathrm{mm}^{3}\right)\end{array}$ & Reference \\
\hline 79 & M & Degenerative valve disease & n.a. & None & 9,710 & 1) \\
\hline 64 & M & Cirrhosis of liver & n.a. & + & n.a. & 4) \\
\hline 48 & M & Implantation of a disc prosthesis & 2 years & + & 12,500 & 5) \\
\hline 32 & M & Vasectomy & 6 weeks & None $^{a}$ & 12,300 & 6) \\
\hline 66 & M & $\begin{array}{l}\text { Colon resection for villous adenoma } \\
\text { Total hip replacement }\end{array}$ & 1 year & None $^{b}$ & 9,400 & 7) \\
\hline 59 & M & $\begin{array}{l}\text { Nephrectomy for renal cell carcinoma } \\
\text { Hardware placed in his ankles } \\
\text { Scalp laceration that required suturing }\end{array}$ & 2 weeks & None & n.a. ${ }^{c}$ & 8) \\
\hline 78 & $\mathrm{~F}$ & None & n.a. & None & n.a. & 9) \\
\hline 50 & M & Mitral regurgitation & n.a. & None & 8,380 & Our case \\
\hline
\end{tabular}

$\mathrm{F}$ = female; $\mathrm{M}$ = male; n.a. = not applicable/not available. ${ }^{\mathrm{a} D}$ Developed a week after symptom onset. ${ }^{\mathrm{b}}$ Developed over the next several days after symptom onset. 'Leukocytosis was not observed in this case.

と一致する。また， 7 例中 4 例 $(57.1 \%)$ は皮膚切開や人工 物の挿入を伴う手術歴を有した ${ }^{5) ~ 8)}$. このうち 2 例は手術か ら NVE 発症までに 1 年以上の期間があり ${ }^{5) 7}$, 手術が感染の 契機であったとすると，S. warneri による NVE は緩徐な進行 を呈する場合がある。一方で，本例のように手術歴，体内人 工物, 易感染性がない症例は少ない（7 例中 2 例 $)^{1) 9)}$. 本例 の感染契機や細菌の侵入門戸は不明だが，僧帽弁閉鎖不全症 と弁逸脱症があり, 弁逆流による心内膜損傷が感染の温床と なった可能性がある。なお, 脳出血で発症した報告は本例の みであった。

S. warneri は皮膚の常在菌であることから，血液培養で検 出された場合にコンタミネーションと誤認されうる。感染性 心内膜炎を起こしても感染徵候にそしく，潜在性の経過をと りうるため, 気づかれにくい.コアグラーゼ陰性ブドウ球菌 は病原性が低いにも関わらず，NVEの死亡率は，S. aureus や S. viridans による NVE と同等かそれ以上であり，診断の遅れ が不良な予後をもたらしている可能性がある ${ }^{10)}$. S. warneri による感染性心内膜炎は非典型的な臨床像を呈し早期診断が 困難な場合があり，本例のように中枢神経合併症で発症した 場合には特に注意を要する.

※著者全員に本論文に関連し，開示すべきCOI 状態にある企業， 組織, 団体はいずれも有りません.

\section{文献}

1) Diaconu R, Golumbeanu E, Constantin A, et al. Native valve endocarditis with Staphylococcus warneri. BMJ Case Rep 2019;12:e229546.
2) Murdoch DR, Corey GR, Hoen B, et al. Clinical presentation, etiology, and outcome of infective endocarditis in the 21st century: the International Collaboration on EndocarditisProspective Cohort Study. Arch Intern Med 2009;169:463-473.

3) Chu VH, Cabell CH, Abrutyn E, et al. Native valve endocarditis due to coagulase-negative staphylococci: report of 99 episodes from the International Collaboration on Endocarditis Merged Database. Clin Infect Dis 2004;39:1527-1530.

4) Kamath U, Singer C, Isenberg HD. Clinical significance of Staphylococcus warneri bacteremia. J Clin Microbiol 1992;30: 261-264.

5) Stöllberger C, Wechsler-Fördös A, Geppert F, et al. Staphylococcus warneri endocarditis after implantation of a lumbar disc prosthesis in an immunocompetent patient. J Infect 2006;52:e15-e18.

6) Dan M, Marien GJ, Goldsand G. Endocarditis caused by Staphylococcus warneri on a normal aortic valve following vasectomy. Can Med Assoc J 1984;131:211-213.

7) Wood CA, Sewell DL, Strausbaugh LJ. Vertebral osteomyelitis and native valve endocarditis caused by Staphylococcus warneri. Diagn Microbiol Infect Dis 1989;12:261-263.

8) Bhardwaj B, Bhatnagar UB, Conaway DG. An Unusual presentation of native valve endocarditis caused by Staphylococcus warneri. Rev Cardiovasc Med 2016;17:140-143.

9) Kini GD, Patel K, Parris AR, Tang JS. An unusual presentation of endocarditis caused by Staphylococcus warneri. Open Microbiol J 2010;4:103-105.

10) Chu VH, Woods CW, Miro JM, et al. Emergence of coagulasenegative staphylococci as a cause of native valve endocarditis. Clin Infect Dis 2008;46:232-242. 


\title{
Abstract \\ A case of subcortical hemorrhage due to infective endocarditis caused by Staphylococcus warneri without fever and leukocytosis
}

\author{
Tomone Taneda, M.D. ${ }^{1)}$, Takuya Konno, M.D., Ph.D. ${ }^{1)}$, Ayaka Ono, M.D. ${ }^{1)}$, \\ Takayoshi Tokutake, M.D., Ph.D. ${ }^{1)}$ and Osamu Onodera, M.D., Ph.D. ${ }^{1)}$ \\ ${ }^{1)}$ Department of Neurology, Brain Research Institute, Niigata University
}

A 50-year-old man with mitral regurgitation presented with right frontal subcortical hemorrhage. Although he had no fever and his white blood cell count was in the normal range, CT angiography demonstrated a micro cerebral aneurysm, and all three blood cultures were positive for Staphylococcus warneri (S. warneri). Thus, we diagnosed him with infective endocarditis. His condition improved successfully by immediate antibiotics and cerebral aneurysm clipping. S. warneri is a member of coagulase-negative staphylococci that are low-virulence and resident flora of the skin. $S$. warneri rarely causes infective endocarditis on native valves. Infective endocarditis caused by $S$. warneri manifests insidious course without inflammatory reactions such as fever and leukocytosis, and thus, diagnosis can be delayed. Attention should be paid to a patient who develops subcortical hemorrhage without a history of hypertension or inflammatory reactions as in this case.

(Rinsho Shinkeigaku (Clin Neurol) 2021;00:000-000)

Key words: Staphylococcus warneri, coagulase-negative staphylococci, infective endocarditis, infectious intracranial aneurysms, subcortical hemorrhage 